\title{
Public Values Related to Decisions in the Tank Waste Remediation System Program
}
L. L. Armacost
D. von Winterfeldt
J. Creighton
M. Robershotte

October 1994

Prepared for the U.S. Department of Energy under Contract DE-AC06-76RLO 1830

Pacific Northwest Laboratory

Operated for the U.S. Department of Energy

by Battelle Memorial Institute 


\title{
DISCLAIMER
}

This report was prepared as an account of work sponsored by an agency of the United States Government. Neither the United States Government nor any agency thereof, nor Battelle Memorial Institute, nor any of their employees, makes any warranty, expressed or implied, or assumes any legal liability or responsibility for the accuracy, completeness, or usefulness of any information, apparatus, product, or process disclosed, or represents that its use would not infringe privately owned rights. Reference herein to any specific commercial product, process, or service by trade name, trademark, manufacturer, or otherwise does not necessarily constitute or imply its endorsement, recommendation, or favoring by the United States Government or any agency thereof, or Battelle Memorial Institute. The views and opinions of authors expressed herein do not necessarily state or reflect those of the United States Government or any agency thereof.

\author{
PACIFIC NORTHWEST LABORATORY \\ operated by \\ BATTELLE MEMORIAL INSTITUTE \\ for the \\ UNITED STATES DEPARTMENT OF ENERGY \\ under Contract DE-ACO6-76RLO 1830
}

Printed in the United States of America

Available to DOE and DOE contractors from the

Office of Scientific and Technical Information, P.O. Box 62, Oak Ridge, TN 37831; prices available from (615) 576-8401. FTS 626-8401.

Available to the public from the National Technical Information Service, U.S. Department of Commerce, 5285 Port Royal Rd., Springfield, VA 22161. 


\title{
Public Values Related to Decisions in the Tank Waste Remediation System Program
}

\author{
L. L. Armacost \\ D. von Winterfeldt ${ }^{(a)}$ \\ J. Creighton ${ }^{(\mathbf{b})}$ \\ M. Robershotte
}

October 1994

Prepared for

the U.S. Department of Energy

under Contract DE-AC06-76RLO 1830

Pacific Northwest Laboratory

Richland, Washington 99352

(a) University of Southern California

(b) Creighton \& Creighton 



\section{Contents}

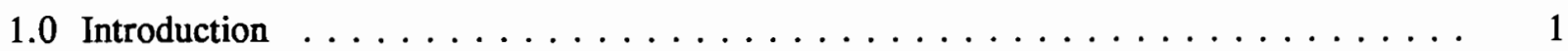

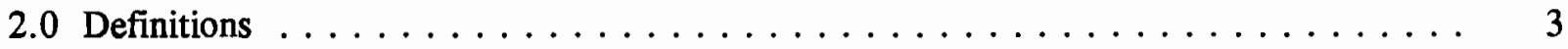

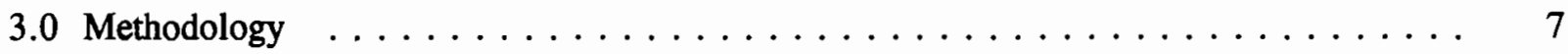

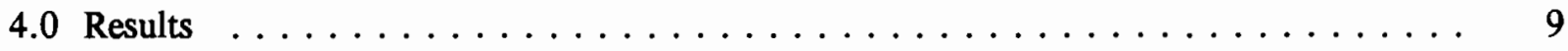

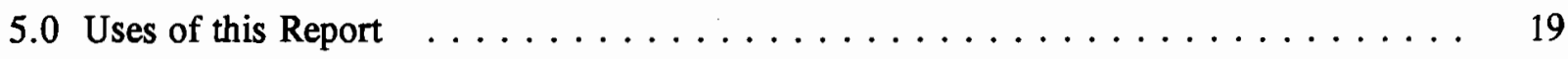

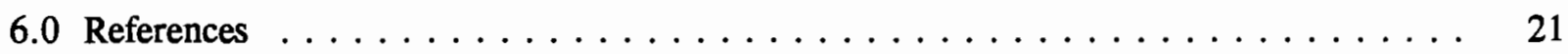

Appendix A - Comprehensive List of Stakeholder Values $\ldots \ldots \ldots \ldots \ldots$. . . . .

Appendix B - Stakeholder Values by Source $\ldots \ldots \ldots \ldots \ldots \ldots \ldots \ldots \ldots$ 


\section{Figures}

1 A Fundamental Objectives Hierarchy $\ldots \ldots \ldots \ldots \ldots \ldots \ldots \ldots$

2 High-Level Value Tree for TWRS End Values $\ldots \ldots \ldots \ldots$

3 High-Level Value Tree for TWRS Means Values $\ldots \ldots \ldots \ldots 11$

4 High-Level Value Tree for TWRS Process Values $\ldots \ldots \ldots \ldots \ldots \ldots$

\section{Tables}

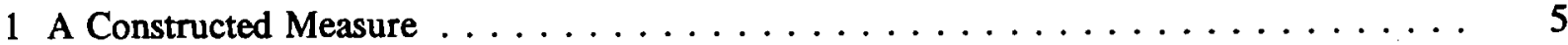

2 TWRS Values, Sub-Values, and Measures $\ldots \ldots \ldots \ldots$ 


\subsection{Introduction}

Managers of the Tank Waste Remediation System (TWRS) Program have to make numerous decisions, ranging from the strategic decisions on the fundamental tank cleanup goals to technical decisions on which types of equipment to use in mechanical retrieval of wastes. Furthermore, many of these decisions have to be made repeatedly (e.g., the annual allocation of research and development funds to TWRS activities).

These decisions have many potential consequences in terms of risks to workers, risks to the public, environmental impacts, and economic development and cost. Because these consequences affect the values of many parties, the consequences need to be evaluated in terms that are accepted and understood by the interested parties. Therefore, an effort needs to be made to incorporate public concerns and values into the TWRS decision-making process.

Previous TWRS-related studies have made such efforts by going out into the community and by interviewing representatives of many different organizations concerned with TWRS decisions. For example, as part of the Tank Waste Disposal Program Redefinition (Grygiel et al. 1991), selected groups were interviewed to elicit their values and concerns regarding the redefinition alternatives. These groups included the Washington Department of Ecology, the Oregon Department of Environment, the Washington State Governor's Office, Westinghouse Hanford Company, Pacific Northwest Laboratory (PNL), the U.S. Department of Energy (DOE) Richland Operations Office, and DOE Headquarters. The values obtained in these interviews were used to develop criteria and measures for evaluating redefinition options.

More recent efforts to obtain a list of values for TWRS decision-making include The Future for Hanford: Uses and Cleanup (Working Group 1992), the Hanford Tank Waste Task Force (HTWTF 1993), the Tank Waste Decision Analysis Report (Johnson et al. 1993), and the Tank Waste Remediation System Integrated Technology Plan (DOE-RL 1994). In addition, values were expressed directly in several studies related to renegotiating the Tri-Party Agreement (e.g., "Washington and Oregon State Department of Ecology Policy Guidance for Hanford WM and ER" and the "TWRS New Technical Strategy." $(a, b, c, d)$ In some of these cases, values were used in decision-making by translating them into technical criteria for option evaluation. In other cases, the values simply expressed desired directions for consideration in technical planning.

(a) Memo from M. Riveland, Washington State Department of Ecology, dated July 21, 1993, to the public: Attachment 1, Hanford Waste Management and Environmental Policy Guidance, dated July 20, 1993; Attachment 2, Hanford Tank Waste Remediation System Negotiations Working Positions, dated July 20, 1993.

(b) Memo from M. L. Blazek and R. Patt, Oregon Department of Energy, dated February 9, 1993, to Leave or Retrieve Subcommittee, Criteria for Proposed Tank Waste Tri-Party Agreement Milestone Changes.

(c) Memo from M. Power, Washington State Department of Ecology, dated February 16, 1993, to Nuclear Waste Advisory Council Members, Criteria for Assessing Hanford's Tank Waste Remediation System Proposals.

(d) The "TWRS New Technical Strategy" was presented as a staff recommendation to the TWRS Leadership Council on February 4 and 5, 1993. 
The purpose of this report is to review and integrate this past work on values and to create a master list of values in order to

- create a consistent value framework for the numerous TWRS decisions

- efficiently and effectively use public values in the decision-making process by updating this report on a regular basis to ensure that the information represents the public's current views

- provide guidance about using values in technical TWRS decisions.

Section 2.0 defines some of the key terms used in this report. Section 3.0 describes the methodology used for identifying and organizing values. Section 4.0 describes the results, with Appendix A containing a master list of values created by this review. Section 5.0 explains the practical applications of the master list of values for decision-makers. 


\subsection{Definitions}

Values can describe about an activity what is good or bad, desirable or undesirable, moral or immoral, and fair or unfair. Values are held by people, groups, or organizations. They provide a set of guidelines by which these individuals, groups, or organizations approach decisions. Values are expressed in different ways. They can be stated as moral imperatives, directions of preference, or desired states. They find their ways into technical analyses as constraints, goals, objectives, or criteria.

Values are often stated in a rather abstract form (e.g., "protect worker health"). To make them useful for technical decision-making, two steps are necessary. First, they need to be expressed in much more specific terms (e.g., "reduce cancer risks to workers from handling of radioactive wastes during normal operations"). Second, measures must be found (or constructed) to estimate the degree to which values have been realized (e.g., "determine annual cumulative worker risks due to radionuclide exposure").

To define values more specifically, value trees (also known as objectives hierarchies) are used. A simplified example is shown in Figure 1. A value tree has very high-level values at its root and more detailed values at its branches and twigs. The logic of splitting up a value is in specification: the lower-level branch and twig values explain what the higher-level (roots) values mean.

Another distinction between ends values, means values, and process values can be made to construct or discover the relationships among expressed values:

- Ends values are important in and by themselves (i.e., no other reason needs to be given as to why they are important). Ends values can be recognized by the self-evident answer when someone asks why they are important. For example, protecting the health and safety of the public is a value that needs little or no further justification. In making a decision, the alternatives under consideration satisfy ends values in differing degrees.

- Means values can be recognized by asking why each value is important and answering that it helps to achieve some other value (an ends value). For example, reducing air pollution is a means value because it contributes to the ends values of protecting human health and safety and protecting the environment. As with ends values, the alternatives considered in a decision satisfy means values in differing degrees. 


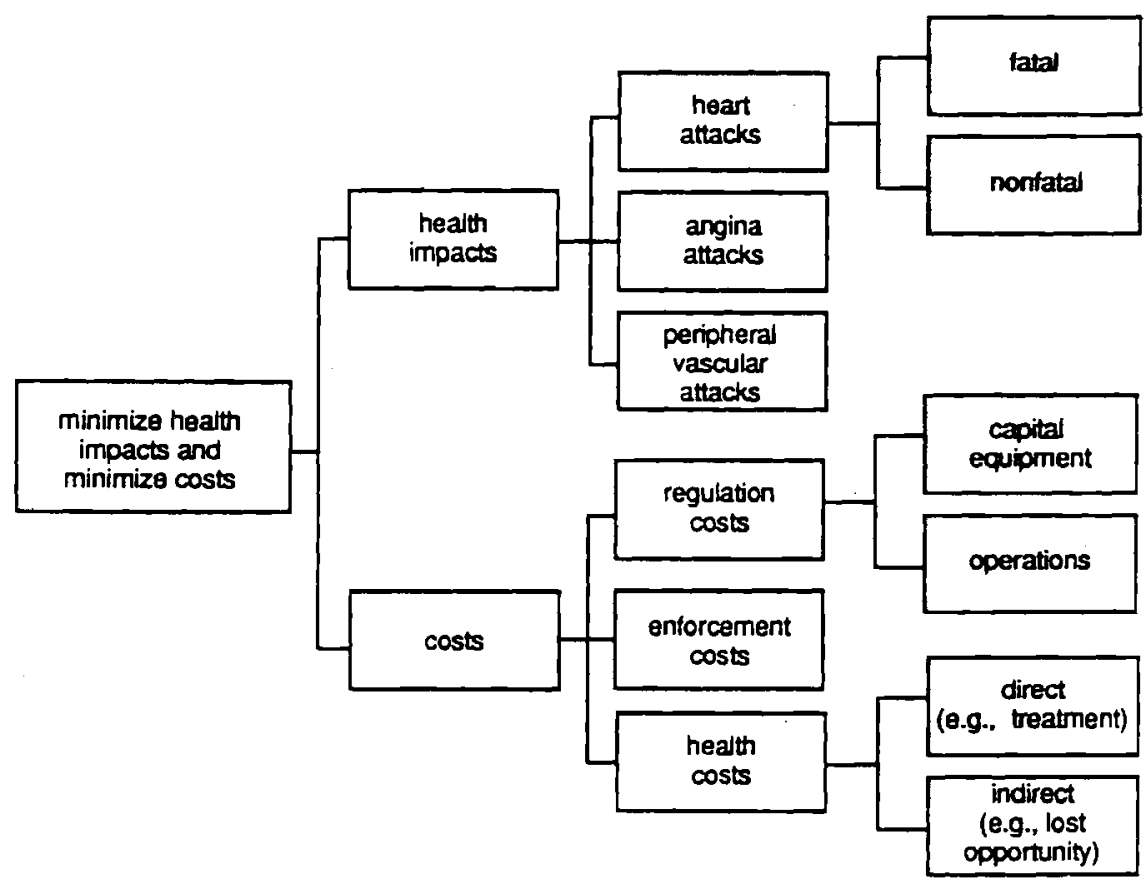

Figure 1. A Fundamental Objectives Hierarchy (Keeney 1992)

- Process values relate to how a decision is to be made or carried out, for example, whether the decision process is fair and equitable, whether it addresses public concerns, or whether it involves members of the public. Often, the actual decision itself is neutral with respect to process values. For example, different cleanup alternatives do not differentiate in terms of how well the public involvement process was done. However, process values are important because they point out ways to improve the designs of decision-making processes.

After values have been expressed in more specific terms and separated into ends, means, and process values, the next step is to make values useful for the technical decision-making process. This is facilitated by developing measures for quantifying and evaluating each value. Measures can be either natural or constructed. Natural (existing) measures are usually obvious and commonly used - as in the case of using an annual cumulative worker risk measurement for cancer risk. Natural measures are generally preferable to constructed measures; however, when no natural measures exist, constructed measures are developed individually for a specific decision in a specific context. The constructed measures express in words what the associated value is meant to address. Table 1 shows an example of a constructed measure for biological impacts at proposed power plant sites (Keeney 1992). 
Table 1. A Constructed Measure

\begin{tabular}{|c|c|}
\hline Attribute Level & Description of Attribute Level \\
\hline 0 & $\begin{array}{l}\text { Complete loss of } 1.0 \mathrm{mi}^{2} \text { of land, which is entirely in agricultural use or is } \\
\text { entirely urbanized; no loss of any "native" biological communities. }\end{array}$ \\
\hline 1 & $\begin{array}{l}\text { Complete loss of } 1.0 \mathrm{mi}^{2} \text { of primarily }(75 \%) \text { agricultural habitat with loss of } \\
25 \% \text { of second-growth forest; no measurable loss of wetlands or endangered } \\
\text { species habitat. }\end{array}$ \\
\hline 2 & $\begin{array}{l}\text { Complete loss of } 1.0 \mathrm{mi}^{2} \text { of land which is } 50 \% \text { farmed and } 50 \% \text { disturbed in } \\
\text { some other way (e.g., logged or new second-growth); no measurable loss of } \\
\text { wetlands or endangered species habitat. }\end{array}$ \\
\hline 3 & $\begin{array}{l}\text { Complete loss of } 1.0 \mathrm{mi}^{2} \text { of recently disturbed (e.g., logged, plowed) habitat } \\
\text { plus disturbance to surrounding previously disturbed habitat within } 1.0 \mathrm{mi} \text { of } \\
\text { site border; or } 15 \% \text { loss of wetlands or endangered species habitat. }\end{array}$ \\
\hline 4 & $\begin{array}{l}\text { Complete loss of } 1.0 \mathrm{mi}^{2} \text { of land which is } 50 \% \text { farmed (or otherwise dis- } \\
\text { turbed) and } 50 \% \text { mature second-growth forest or other undisturbed commun- } \\
\text { ity; } 15 \% \text { loss of wetlands or endangered species habitat. }\end{array}$ \\
\hline 5 & $\begin{array}{l}\text { Complete loss of } 1.0 \mathrm{mi}^{2} \text { of land which is primarily }(75 \%) \text { undisturbed mature } \\
\text { "desert" community; } 15 \% \text { loss of wetlands or endangered species habitat. }\end{array}$ \\
\hline 6 & $\begin{array}{l}\text { Complete loss of } 1.0 \mathrm{mi}^{2} \text { of mature second-growth (but not virgin) forest com- } \\
\text { munity; or } 50 \% \text { loss of big game and upland game birds; or } 50 \% \text { loss of wet- } \\
\text { lands and endangered species habitat. }\end{array}$ \\
\hline 7 & $\begin{array}{l}\text { Complete loss of } 1.0 \mathrm{mi}^{2} \text { of mature community or } 90 \% \text { loss of productive wet- } \\
\text { lands and endangered species habitat. }\end{array}$ \\
\hline 8 & $\begin{array}{l}\text { Complete loss of } 1.0 \mathrm{mi}^{2} \text { of mature virgin forest and/or wetlands and/or } \\
\text { endangered species habitat. }\end{array}$ \\
\hline
\end{tabular}

When developing measures, it is highly desirable that they be understandable and operational. To be understandable, the measure must be clear and involve no ambiguous categories. A measure is operational if it is reasonable to describe the possible consequences with respect to the value. In addition, it must provide a sound basis for judgments about the desirability of the various degrees to which the value might be achieved (Keeney 1992). 



\subsection{Methodology}

The methodology used in this study is described below:

1. The existing documents that include expressions of value related to TWRS were reviewed.

2. A master list was created of all value-related statements in these documents.

3. The high-level values were identified, as stated by the major organizations related to TWRS and then separated into means, ends, and process values.

4. A list of sub-values was created to supplement the list of high-level values.

5. Lists were created of possible measures for each of the sub-values.

To conduct the first two steps of this methodology, the following documents, letters, and study notes were reviewed:

- The Future for Hanford: Uses and Cleanup (Working Group 1992)

- Hanford Tank Waste Task Force (HTWTF 1993)

- "Washington and Oregon State Department of Ecology Policy Guidance for Hanford WM and $\mathrm{ER}^{\prime \prime}(\mathrm{a}, \mathrm{b}, \mathrm{c})$

- TWRS New Technical Strategy ${ }^{(\mathrm{d})}$

- Tank Waste Disposal Program Redefinition (Grygiel et al. 1991)

- Tank Waste Technical Options Report (Boomer et al. 1993)

- Phase 1 Involvement for Potential Stakeholders of the VOC-Arid Integrated Demonstration (McCabe 1992)

(a) Memo from M. Riveland, Washington State Department of Ecology, dated July 21, 1993, to the public: Attachment 1, Hanford Waste Management and Environmental Policy Guidance, dated July 20, 1993; Attachment 2, Hanford Tank Waste Remediation System Negotiations Working Positions, dated July 20, 1993.

(b) Memo from M. L. Blazek and R. Patt, Oregon Department of Energy, dated February 9, 1993, to Leave or Retrieve Subcommittee, Criteria for Proposed Tank Waste Tri-Party Agreement Milestone Changes.

(c) Memo from M. Power, Washington State Department of Ecology, dated February 16, 1993, to Nuclear Waste Advisory Council Members, Criteria for Assessing Hanford's Tank Waste Remediation System Proposals.

(d) The "TWRS New Technical Strategy" was presented as a staff recommendation to the TWRS Leadership Council on February 4 and 5, 1993. 
- Assessing Technologies for the Treatment of Tank Wastes at DOE's Hanford Site (von Winterfeldt 1993)

- Tank Waste Decision Analysis Report (Johnson et al. 1993)

In order to avoid changing the interpretation and meaning of the value statements in these documents, the results of steps 1-3 of the methodology present the values exactly as stated in the above listed documents. Steps 4 and 5 necessarily involved some interpretation and judgment by the authors, and therefore will require review and valadation by the stakeholders.

The products of this methodology are the following:

- a master list of all value statements identified in the reports listed above

- three value trees describing the key (highest level) ends, means, and process values identified in the documents listed above

- detailed value tables that define menus of sub-values and measures for the sub-values.

These products are described and discussed in the next section. 


\subsection{Results}

The first result is a master list of 99 value statements found in the referenced documents (Appen$\operatorname{dix}$ A). Appendix B shows the same value statements listed by the sources from which they were obtained. The master list of values contains a mixture of ends, means, and process values. For example, the Hanford Tank Waste Task Force (HTWTF 1993) lists "protect public/worker health and safety," which is clearly an ends value. It also states "training for everyone who will be on the site (as) critically important," which is a means value for health and safety and environmental protection. As an example of a process value, this report requests that TWRS activities "reduce paperwork, analytic, and decision making redundancy." Furthermore, the master list describes values on very different levels of specificity. For example, the values of the report on The Future for Hanford: Uses and Cleanup (Working Group 1992) are all very high level (e.g., "protect the Columbia River" and "clean up areas of high future use value"). Other reports list some very specific values. For example, The Hanford Tank Waste Task Force (HTWTF 1993) lists, among other values, "characterization of tank waste" and "minimize transportation," which are possible sub-values.

The second result of the methodology applied in this report provides some structure to the long master list of values shown in Appendix A. Three high-level value trees were constructed using the logic of separating ends, means, and process values. These are shown in Figures 2 through 4 . The value statements of the master list that are associated with each high-level value are cross-referenced by their respective numbers in these figures. All specific value statements in the master list are thus accounted for.

Two documents were considered especially important when creating these three trees: The Future for Hanford: Uses and Cleanup (Working Group 1992) and The Hanford Tank Waste Task Force (HTWTF 1993). The reason for attaching special importance to these documents was that they specifically addressed value issues, they involved representatives of many views, and they included public debate. The 14 shaded values in Figures 2 through 4 were taken verbatim from these two reports.

The third result of the methodology are menus of sub-values and measures for the values in Figures 2 through 4 . The result is shown in Table 2, with the sub-values indented under their respective values, and the measures indented under their respective sub-values. The sub-values and measures are based upon the authors' judgments and will therefore require review by the public.

It is important to stress that these sub-values and measures are, at this point, neither mutually exclusive nor exhaustive. They are intended as a menu from which analysts and decision makers can choose when facing the evaluation of alternatives. It is also important to point out that for many values no simple natural measure currently exists, and thus constructed measures like the one in Table 1 need to be developed. Future work, therefore, is required to 1) ensure that the sub-values are mutually exclusive and exhaustive, 2) identify a richer list of natural measures, and 3) develop additional constructed measures. 


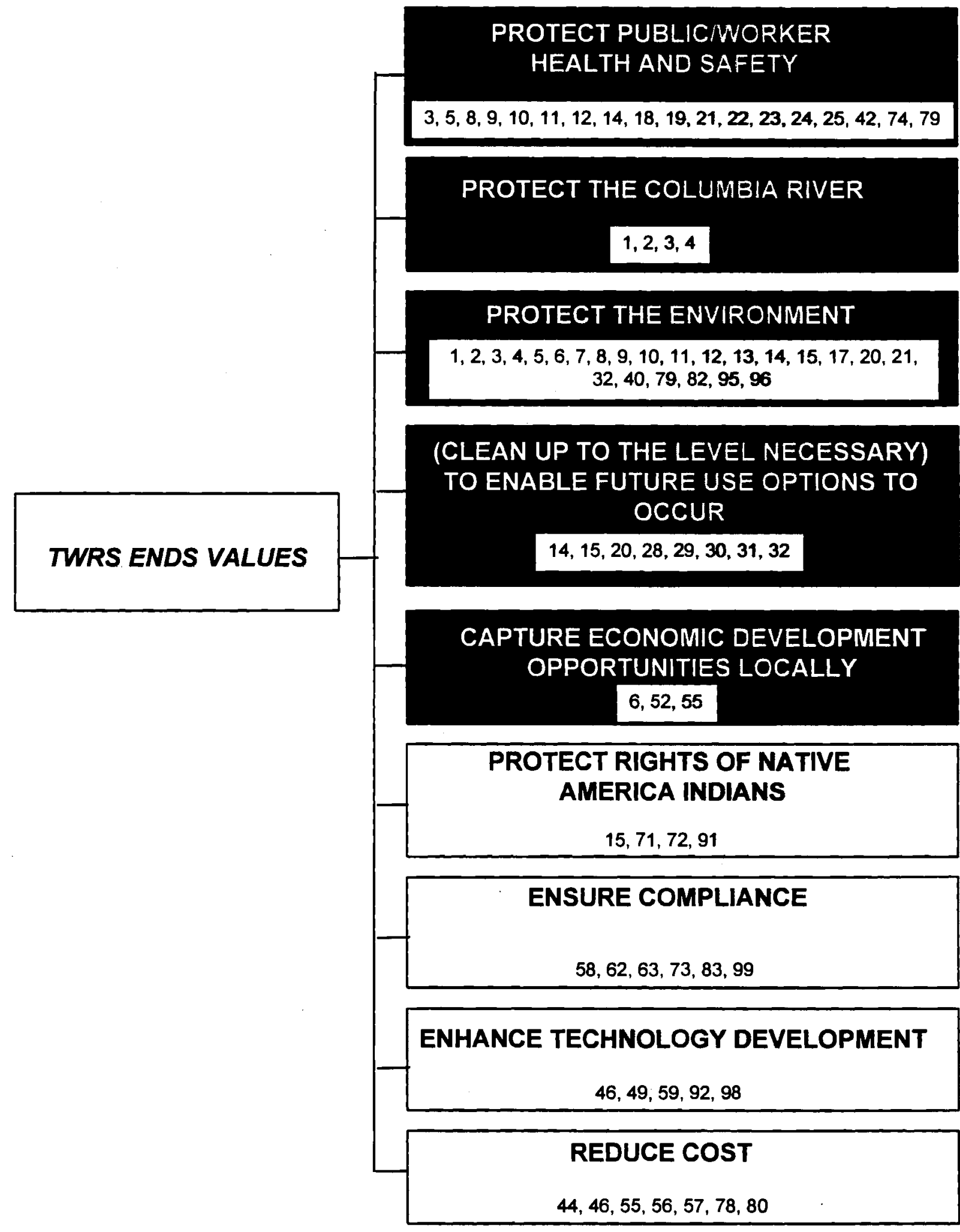

Figure 2. High-Level Value Tree for TWRS End Values 


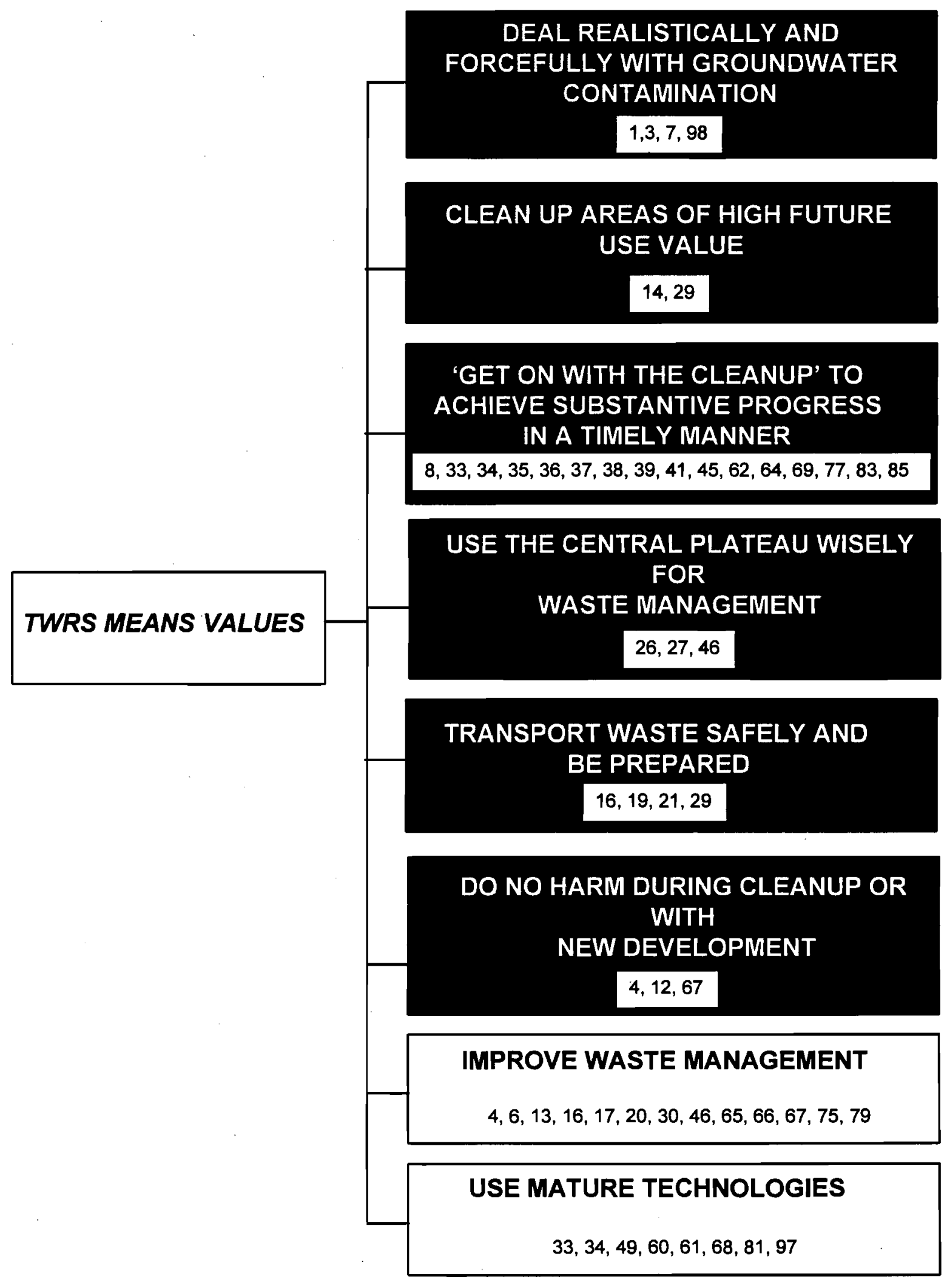

Figure 3. High-Level Value Tree for TWRS Means Values 


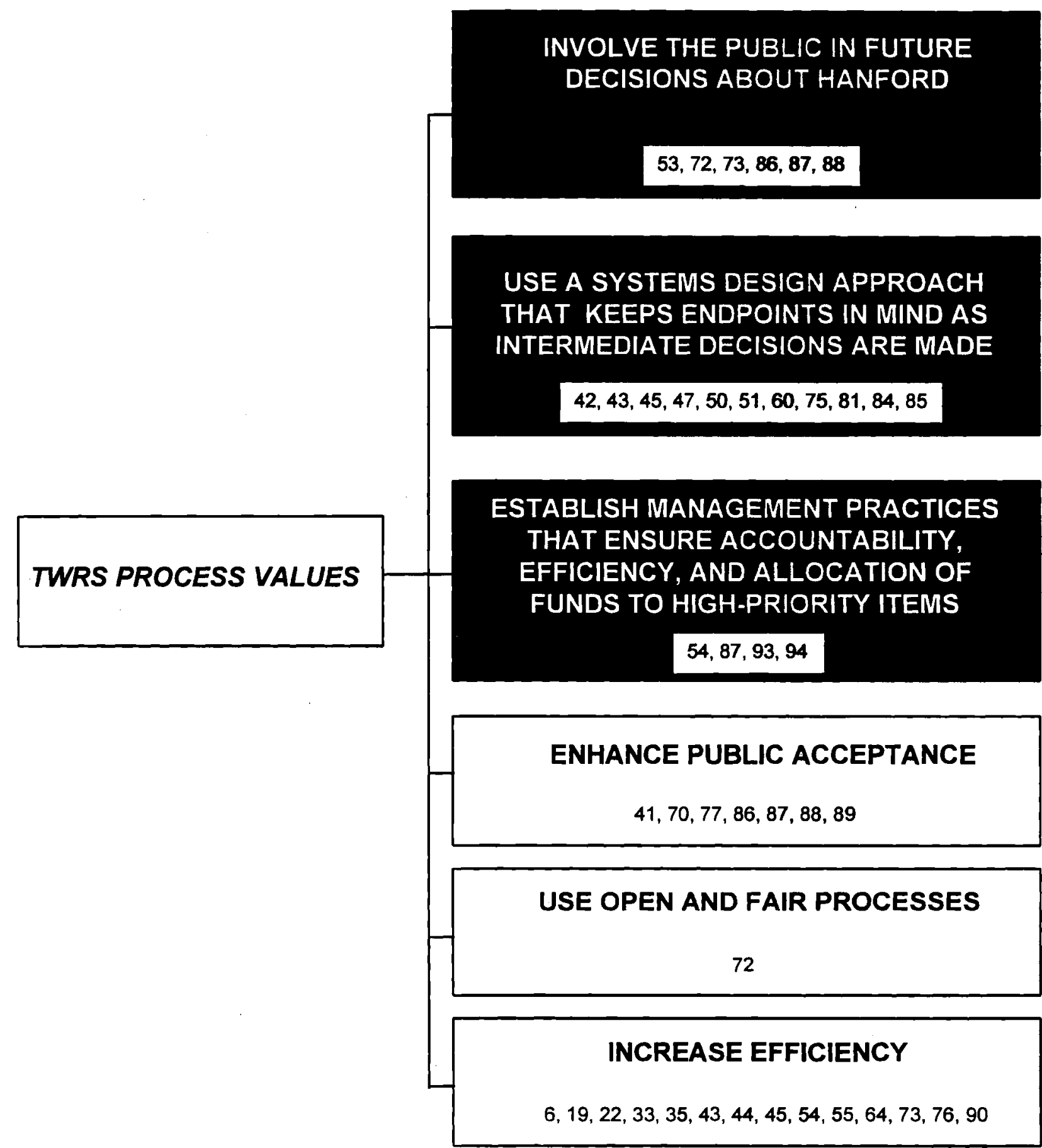

Figure 4. High-Level Value Tree for TWRS Process Values 
Table 2. TWRS Values, Sub-Values, and Measures

1 Protect Public/Worker Health and Safety ${ }^{(a)}$

Protect Public Health and Safety

Reduce Risks from Normal Operations - Facility

Reduce Radiological Risks

Annual population cancer risk

Annual inventory of radionuclides

Annual offsite dose (rem)

Reduce Non-Radiological Risks

Hazard Index

Amount and toxicity of hazardous materials

Reduce Accident Risks - Facility

Reduce Radiological Risks

Annual population cancer risk (probability $x$ consequences)

Annual offsite dose (rem)

Number of cancers in a severe accident (consequence)

Maximum credible number of cancers in a severe accident

\section{Reduce Non-Radiological Risks}

Hazard index

Amount and toxicity of hazardous materials

Reduce Accident Risks - Transportation

Annual population risk from transportation

Vehicle miles off site

Protect Worker Health and Safety

Reduce Risks From Normal Operations

Reduce Radiological Risks

Annual worker cancer risk

Annual inventory of radionuclides

Annual offsite dose (rem)

(a) Values 1 through 9 are end values as shown in Figure 2. 


\begin{tabular}{|c||} 
Reduce Non-Radiological Risks \\
Hazard index \\
Amount and toxicity of hazardous materials \\
Reduce Accident Risks - Facility \\
Reduce Radiological Risks \\
Annual worker cancer risk (probability $x$ consequences) \\
Annual offsite dose (rem) \\
Number of cancers in a severe accident (Consequence) \\
Maximum credible number of cancers in a severe accident \\
Reduce Non-Radiological Risks \\
Hazard index \\
Amount and toxicity of hazardous materials \\
Annual construction worker risk \\
Industrial lost worker hours \\
Reduce Accident Risks - Transportation \\
Annual worker risk from transportation \\
Vehicle miles off site \\
Number of railcar shipments to repository \\
Cubic meters of HLW transported
\end{tabular}




\section{Protect the Environment}

\section{Protect Animals}

Number and type of animals lost

Reproductive success rate

Changes in threshold/endangered species

Selected constructed measures

\section{Protect Plants}

Number and type of plants lost

Biodiversity index

Soil fertility

Changes in threshold/endangered species

Selected constructed measures

\section{Reduce Soil Pollution}

Amount and toxicity of polluted soil

Soil fertility

Cubic meters of polluted soil

Selected constructed measures

\section{Reduce groundwater pollution}

Gallons of liquids at toxicity level

Selected constructed measures

\section{Reduce Air Pollution}

Tons of pollutants (by type) emitted

Selected constructed measures

\section{Protect Sites With Special Religious and Cultural}

Relevance

Percent defilement of known sacred sites

Selected constructed scales

Protect Historical and Archeological Sites

Percent defilement

Selected constructed scales

4 (Clean Up to the Level Necessary to) Enable Future Use Options to Occur

Increase Area of Unrestricted Use

Square miles of unrestricted use

Percent of site that is available for unrestricted use

Maintain Opportunities for Restricted Use Areas

Inventory of materials left in restricted areas 


\section{Capture Economic Development Opportunities Locally}

Provide Steady Employment

Average increase (decrease) in employment per year

Maximum increase (decrease) in a given time period

Number of additional (less) employees

Increase Diversity of Employment

Number of types of employment

Spin off industries

Selected constructed scales

Reduce Stresses on Local Infrastructure

Selected constructed scales

6 Protect Rights of Native American Indians

Compliance with Treaties

Selected constructed measures

Protect Native and Traditional Uses of the Environment

Percent of restrictions of access to Hanford lands

Number of restricted acres

Selected constructed measures

\section{Ensure Compliance}

With Laws and Regulations

Selected constructed measures

With Agreements

Selected constructed measures

With DOE Orders

Selected constructed measures 


\section{Enhance Technology Development \\ Applicability to Other Missions at Hanford \\ Number of missions \\ Selected constructed measures \\ Applicability to Other Sites \\ Number of sites \\ Selected constructed measures \\ Applicability to Other Problems \\ Number of other problems \\ Selected constructed measures}

\section{Reduce Cost}

Total Life Cycle Cost

Total discounted cost

Capital cost plus operations and maintenance

\section{Cost Profile Considerations}

Maximum annual percent increase in program cost

Maximum annual percent increase in site budget

10 Deal Realistically and Forcefully with Groundwater ${ }^{(a)}$ Contamination

11 Clean Up Areas of High Future Use Value

Number of acres cleaned

12 "Get on With the Cleanup" to Achieve Substantive Progress in a Timely Manner

\section{Early Closure}

\section{Meet 7}

TPA Milestones

Number of milestones met

Number of milestones not met

13 Use the Central Plateau Wisely for Waste Management

14 Transport Waste Safely and Be Prepared

Number of transport accidents minor/major

Emergency preparation readiness evaluations

(a) Values 10 through 17 are means values as shown in Figure 3. 


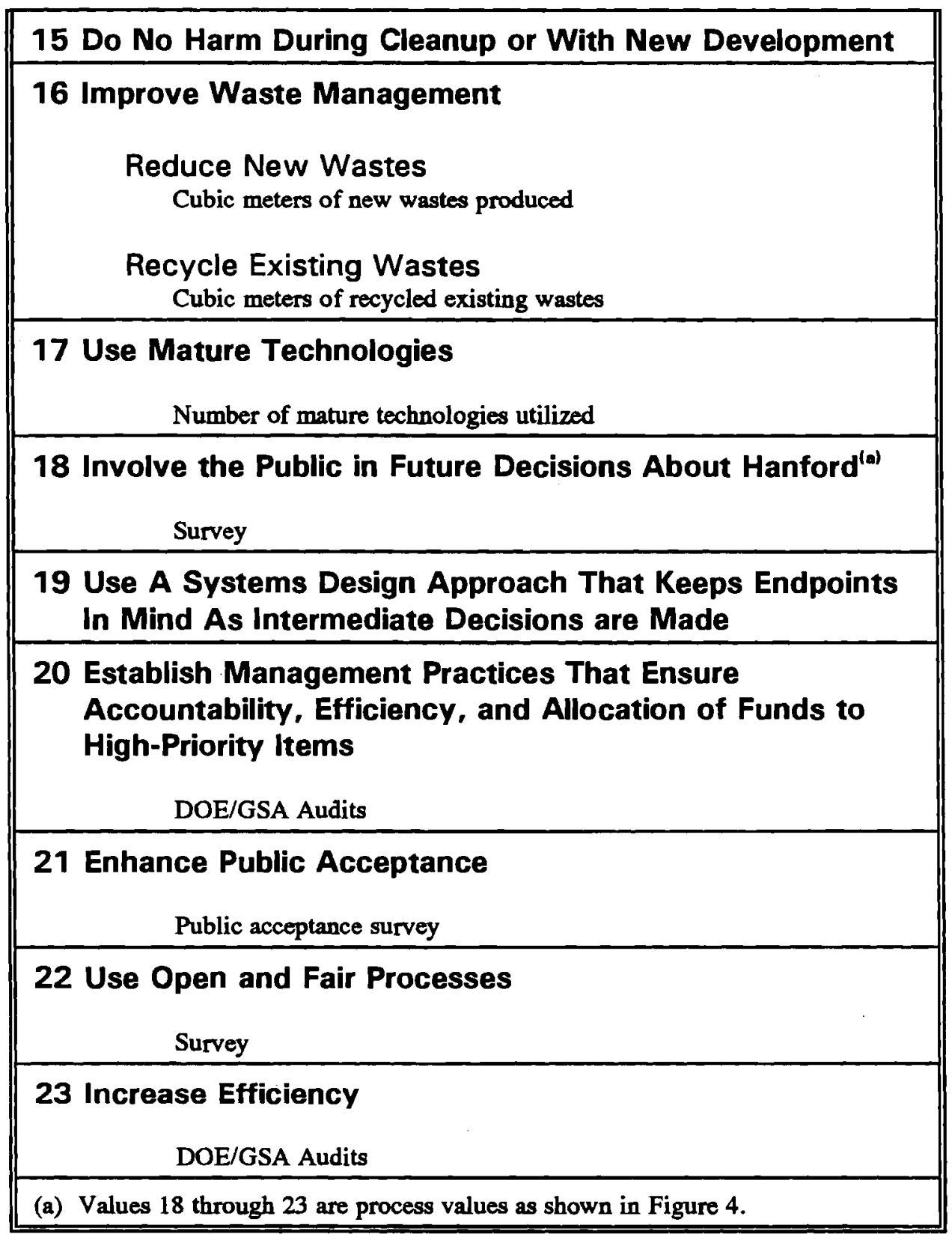




\subsection{Uses of this Report}

This document is intended to be used as a common source by engineers, analysts, and decisionmakers to aid in the TWRS and other Hanford decision processes. It is recommended that this document be treated as an evolving, working report, which will be updated on a regular basis to capture any additional values that are of concern to the stakeholders and to omit those that are no longer relevant. There are several specific uses for the lists of values and measures summarized in this report:

- as a repository of existing knowledge about the values of individuals, groups, and organizations interested in Hanford activities; since this report represents only a snapshot in time and since values change, the lists should be continually updated

- as a basis for understanding the values of individuals, groups, and organizations, and as a reminder to the technical community about what external parties care about and why they care about it

- as a means of defining the potential list of values to be considered in decision-making and for suggesting relevant measures for the evaluation of alternatives

- as a framework for communicating with individuals, groups, and organizations interested in Hanford activities.

At the first level, the lists of values shown in Figures 2 through 4 simply summarize what is currently known about values regarding Hanford. In the attempt to assemble these values, a conscious attempt was made not to change or even rephrase the statements made by the authors of the reports that stated these values. The report distinguishes between ends, means, and process values, but this distinction does not imply that one set of values is more important than another, or that one set of values should be used in TWRS analyses while others should not. In fact, TWRS managers and analysts should survey the complete set of values, regardless of the categories to which they were assigned in this report and determine whether they are relevant in the context of the particular analysis. It should be understood that the list of values and measures will change over time.

On a second level, the lists of values also serve to enhance the technical community's understanding of the different concerns of external individuals, groups, and organizations regarding decisions about Hanford cleanup. In fact, it would be desirable to have explicit lists of values for different groups such as the Indian Nations, regulatory agencies, local communities, and farmers, so that the technical community can begin to understand the value-relevant view points by which these different groups and organizations approach decisions at Hanford.

The values shown in Figures 2 through 4 are very high-level values. Depending upon the decision, more detailed values may need to be considered to facilitate the evaluation of alternatives. Therefore, a menu of possible sub-values was developed as shown in Table 2. This menu of subvalues is, at this stage, meant to be illustrative and not comprehensive. 
A third use of the list of values is for decision-making in specific TWRS contexts. This involves the following steps in actually using the figures and tables in this report:

1. Define the problem statement.

2. Define the alternatives to which the values should be applied.

3. Eliminate values that do not differentiate among the alternatives.

4. Identify the proper sub-values from the list in Table 2.

5. Identify the measures that can be used for these sub-values from Table 2. (The measures are shown as the last level of indentation in Table 2.)

6. Evaluate the alternatives using these measures.

Finally, just as this report is intended to communicate to the technical community the values held by external individuals, groups, and organizations, proper uses of these values in technical analyses should feed back the value-relevant information to the external groups. In fact, upon completion of an analysis that uses their values and measures, it should be very easy to communicate to external groups the following ideas and results:

- In the specific problem context that we studied, your values were surveyed and a subset was found to have important discriminators in choosing among the alternatives.

- This subset of values was applied to the problem by measuring the performance of the alternatives against the values - and this assessment formed the factual base of our analysis.

- To aggregate this information further to ranking the alternatives, weightings need to be applied to the values. Note that no weightings have been applied in this document. Weightings on the values have to come from the stakeholder groups. 


\subsection{References}

Boomer, K. D., S. K. Baker, A. L. Boldt, J. D. Galbraith, J. S. Garfield, C. E. Golberg, B. A. Higley, L. J. Johnson, M. J. Kupfer, R. M. Marusich, R. J. Parazin, A. N. Praga, G. W. Reddick, E. J. Slaathaug, L. M. Swanson, T. L. Waldo, and C. E. Worcester. 1993. Tank Waste Technical Options Report. WHC-EP-0616, Westinghouse Hanford Company, Richland, Washington.

Grygiel, M. L., C. A. Augustine, M. A. Cahill, J. S. Garfield, M. E. Johnson, M. J. Kupfer, G. A. Meyer, J. H. Roecker, L. K. Holton, V. L. Hunter, and M. B. Triplet. 1991. Tank Waste Disposal Program Redefinition. WHC-EP-0475, Westinghouse Hanford Company, Richland, Washington.

Hanford Tank Waste Task Force (HTWTF). 1993. Hanford Tank Waste Task Force (Final Report). Submitted by the Hanford Waste Tank Task Force to the Washington State Department of Ecology, U.S. Department of Energy, and U.S. Environmental Protection Agency.

Johnson, M. E., M. L. Grygiel, P. A. Baynes, J. P. Bekemeier, B. D. Zimmerman, and M. B. Triplett. 1993. Tank Waste Decision Analysis Report. WHC-EP-0617, Westinghouse Hanford Company, Richland Washington.

Keeney, R. L. 1992. Value-Focused Thinking. A Path to Creative Decisionmaking. Harvard University Press, Cambridge, Massachusetts.

McCabe, G. H. 1992. Phase I Involvement for Potential Stakeholders of the VOC-Arid Integrated Demonstration. BHARC-800/93/004, Battelle Seattle Research Center, Seattle, Washington.

U.S. Department of Energy Richland Operations Office (DOE-RL). 1994. Tank Waste Remediation System Integrated Technology Plan. DOE-RL-92-61, DOE-RL, Richland, Washington.

von Winterfeldt, D. 1993. Assessing Technologies for the Treatment of Tank Wastes at DOE's Hanford Site. University of Southern California, California.

Working Group (The Hanford Future Site Uses Working Group). 1992. The Future for Hanford: Uses and Cleanup. The Final Report of the Hanford Future Site Uses Working Group, Chairman Dr. Marshall E. Drummond, Eastern Washington University, Cheney, Washington. 


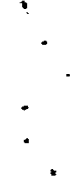


Appendix A

Comprehensive List of Stakeholder Values 


\section{Appendix A}

\section{Comprehensive List of Stakeholder Values}

1. Protect the environment.

2. Protect the Columbia River.

3. Deal realistically and forcefully with groundwater contamination.

4. Do no harm during cleanup or with new development.

5. Address immediate health and environmental risks that need to be addressed.

6. Upgrade Infrastructure.

7. Address leaking tanks and prevent additional leaks without further compounding future remediation efforts.

8. Put wastes in an environmentally safe form, using retrievable waste forms when potential hazards from the waste may require future retrieval and when retrievability does not cause inordinate delays in getting on with the cleanup.

9. Let ultimate best form for the waste drive decisions.

10. Select a waste form that will ensure safe interim storage of this waste.

11. Minimize risks of the public and environment through stabilization and containment pending final cleanup actions.

12. Prevent new harm and risk.

13. Strive for volume minimization.

14. Minimize long-term environmental contamination.

15 Maximize unrestricted land availability by minimizing on-site low-level waste volume.

16. Minimize off-site waste volume.

17. Minimize volume of other system generated waste.

18. Protect public/worker health and safety.

19. Transport waste safely and be prepared.

20. Do not attract other sites' waste for disposal or long-term storage.

21. Minimize transportation of radioactive and hazardous material to and from the site to reduce the risks to the public and the environment.

22. Training for everyone who will be on the site is critically important.

23. Minimize worker/public radiological exposure.

24. Minimize worker industrial hazards.

25. Minimize public transportation hazards.

26. Use the Central Plateau wisely for waste management.

27. 100 years after closure of Hanford - want to be able to use Central Plateau for general use.

28. Clean up to the level necessary to enable the future use option to occur.

29. Clean up areas of high future use value.

30. Strive to minimize the creation, volume, and toxicity of waste requiring on-site disposal. 
31. Provide for the greatest range of possible future uses of the Hanford Site.

32. Minimize irrevocable commitments of land and resources.

33. Do the job expeditiously (schedule progress and assurance).

34. Ensure that cleanup actions are achievable and are conducted in a technically sound and expeditious manner.

35. Minimize time duration for resolving environmental concerns.

36. Minimize campaign duration.

37. Minimize time duration for resolving safety issues.

38. Maximize early immobilization for disposal progress.

39. "Get on with the cleanup" to achieve substantive progress in a timely manner.

40. Contribute to environmental remediation and waste containment, stabilization, storage, and disposal in a safe form.

41. Demonstrate on the ground progress as quickly as possible.

42. Empower safe operations and worker participation in quality implementation.

43. Reduce paperwork, analytic, and decision-making redundancy.

44. Less costly than other options, while still protective of the environment and public/worker health and safety.

45. Move all major facets of cleanup forward and in proper sequence.

46. Keep technical options open that have realistic, cost-effective chances to significantly improve waste management practices over the life of the cleanup and appropriately implement these options.

47. Consider the ability to evaluate, expand upon, or change course based on technical and scientific advancement.

48. Characterization of tank waste.

49. Use the most practicable, timely, available technology, while leaving room for future innovations.

50. Use a systems design approach that keeps end points in mind as intermediate decisions are made.

51. Double-shell tank capacity is important, simpler solutions are preferred.

52. Capture economic development opportunities locally.

53. Involve the public in future decisions about Hanford.

54. Establish management practices that ensure accountability, efficiency, and allocation of funds to high-priority items.

55. Do the job efficiently (cost effective).

56. Minimize total life cycle cost.

57. Minimize discounted costs.

58. Ensure compliance with environmental laws and regulations.

59. Contributions to other missions.

60. Technology assurance.

61. Maximize operability and reliability.

62. Avoid regulatory uncertainty.

63. Ability to achieve regulatory standards with a degree of certainty; now and in the future.

64. Minimize time for institutional control. 
65. Maximize waste conversion to releasable forms.

66. Maximize recycle of materials.

67. Minimize introduction of hazardous chemicals.

68. Utilize simple, reliable, processes and systems as much as possible.

69. Minimize time duration for resolving environmental concerns.

70. Public perception.

71. Tribal rights.

72. Provide for active tribal and public involvement in decision making.

73. Promote closer cooperation with DOE and its contractors, EPA, and the public to seek out and use new and more efficient means to reach compliance and cleanup goals, and to measure progress.

74. Aggressive actions toward tank safety.

75. Resolution of "incidental waste" definition.

76. Reduce the time duration for resolving safety issues and environmental concerns, and assure adequate contingency planning.

77. Show substantial near-term cleanup progress.

78. Reduce long-term waste disposal costs when reductions do not jeopardize safety.

79. Assure removal of largest technically achievable amount of radioactivity from mixed waste before disposal as low-level waste or incidental waste.

80. Economic concerns: budget realities, cost profile.

81. Defensibility of technical solutions.

82. Environmental concerns: biota--natural ecosystem impacts, impacts on special species; non-biota-air contamination.

83. Meet Tri-Party Agreement milestones.

84. Avoid focus on short-term problems.

85. Keep focus on long-term needs and goals.

86. Broad and early stakeholder involvement.

87. Political and institutional support.

88. Maintain evolving strategy in touch with stakeholders.

89. Stakeholder acceptance of final cleanup initiatives.

90. Appropriate use of research and development.

91. Yakima Nation special concerns: ability to exercise rights, cultural rights (practicing religion), concern with desecrating sites of religious significance.

92. Provide maximum flexibility for incorporating improved technology.

93. Understandability and defensibility.

94. Quality Management.

95. Natural Ecosystem Impacts.

96. Impacts on Special Species.

97. Maximize use of mature processes.

98. Maximize flexibility and adaptability for new technologies.

99. Avoid regulatory uncertainty. 


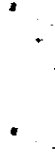

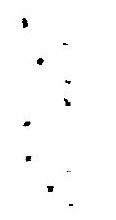


Appendix B

Stakeholder Values by Source 


\section{Appendix B}

\section{Stakeholder Values by Source}

The Future for Hanford: Uses and Cleanup (Working Group 1992)

- Protect the Columbia River.

- Deal realistically and forcefully with groundwater contamination.

- Do no harm during cleanup or with new development.

- Transport waste safely and be prepared.

- Use Central Plateau wisely for waste management.

- Clean up to the level necessary to enable the future use option to occur.

- Clean up areas of high future use value.

- Capture economic development opportunities locally.

- Involve the public in future decisions about Hanford.

Hanford Tank Waste Task Force (HTWTF 1993)

- Protect the environment.

- Address immediate health and environmental risks that need to be addressed.

- Upgrade infrastructure.

- Address leaking tanks and prevent additional leaks without further compounding future remediation efforts.

- Put wastes in an environmentally safe form, using retrievable waste forms when potential hazards from the waste may require future retrieval and when retrievability does not cause inordinate delays in getting on with the cleanup.

- Let ultimate best form for the waste drive decisions.

- Select a waste form that will ensure safe interim storage of this waste.

- Protect public/worker health and safety.

- Do not attract other sites' waste for disposal or long-term storage.

- Minimize transportation of radioactive and hazardous material to and from the site to reduce the risks to the public and the environment.

- Training for everyone who will be on the site is critically important.

- "Get on with the cleanup" to achieve substantive progress in a timely manner.

- Contribute to environmental remediation and waste containment, stabilization, storage, and disposal in a safe form.

- Demonstrate on the ground progress as quickly as possible.

- Empower safe operations and worker participation in quality implementation.

- Reduce paperwork, analytic, and decision-making redundancy. 
- Less costly than other options, while still protective of the environment and public/worker health and safety.

- Move all major facets of cleanup forward and in proper sequence.

- Keep technical options open that have realistic, cost-effective chances to significantly improve waste management practices over the life of the cleanup and appropriately implement these options.

- Consider the ability to evaluate, expand upon, or change course based on technical and scientific advancement.

- Characterization of tank waste.

- Use the most practicable, timely, available technology, while leaving room for future innovations.

- Use a systems design approach that keeps end points in mind as intermediate decisions are made.

- Double-shell tank capacity is important, simpler solutions are preferred.

- Establish management practices that ensure accountability, efficiency, and allocation of funds to high-priority items.

"Washington and Oregon State Department of Ecology Policy Guidance for Hanford WM and $\mathrm{ER}^{\prime \prime}(\mathbf{a}, \mathbf{b}, \mathrm{c})$

- Protect the environment.

- Minimize risks of the public and environment through stabilization and containment pending final cleanup actions.

- Prevent new harm and risk.

- Protect public/worker health and safety.

- Strive to minimize the creation, volume, and toxicity of waste requiring on-site disposal.

- Ensure that cleanup actions are achievable and are conducted in a technically sound and expeditious manner.

- Ensure compliance with environmental laws and regulations.

- Provide for active tribal and public involvement in decision making.

- Promote closer cooperation with DOE and its contractors, EPA, and the public to seek out and use new and more efficient means to reach compliance and cleanup goals, and to measure progress.

- Aggressive actions toward tank safety.

- Resolution of "incidental waste" definition.

- Show substantial near-term cleanup progress.

- Reduce long-term waste disposal costs when reductions do not jeopardize safety.

(a) Memo from M. Riveland, Washington State Department of Ecology, dated July 21, 1993, to the public: Attachment 1, Hanford Waste Management and Environmental Policy Guidance, dated July 20, 1993; Attachment 2, Hanford Tank Waste Remediation System Negotiations Working Positions, dated July 20, 1993.

(b) Memo from M. L. Blazek and R. Patt, Oregon Department of Energy, dated February 9, 1993, to Leave or Retrieve Subcommittee, Criteria for Proposed Tank Waste Tri-Party Agreement Milestone Changes.

(c) Memo from M. Power, Washington State Department of Ecology, dated February 16, 1993, to Nuclear Waste Advisory Council Members, Criteria for Assessing Hanford's Tank Waste Remediation System Proposals. 
- Ensure removal of largest technically achievable amount of radioactivity from mixed waste before disposal as low-level waste or incidental waste.

- Ensure adequate double-shell tank space.

"TWRS New Technical Strategy"(a)

Tank Waste Disposal Program Redefinition (Grygiel et al. 1991)

Tank Waste Technical Options Report (Boomer et al. 1993)

Phase 1 Involvement for Potential Stakeholders of the VOC-Arid Integrated Demonstration (McCabe 1992)

- Maximize unrestricted land availability by minimizing on-site low-level waste volume.

- Minimize time duration for resolving environmental concerns.

- Minimize campaign duration.

- Minimize time duration for resolving safety issues.

- Provide maximum flexibility for incorporating improved technology.

- Minimize total life cycle cost.

- Avoid regulatory uncertainty.

- Minimize time for institutional control.

- Maximize waste conversion to releasable forms.

- Maximize recycle of materials.

- Minimize introduction of hazardous chemicals.

- Utilize simple, reliable, processes and systems as much as possible.

- Minimize time duration for resolving environmental concerns.

- Reduce the time duration for resolving safety issues and environmental concerns.

- Protect public/worker health and safety.

- Ensure compliance with environmental laws and regulations.

- Contributions to other missions.

- Technology assurance.

- Environmental concerns: biota--natural ecosystem impacts, impacts on special species; non-biota-air contamination, groundwater contaminates, surface water contamination (Columbia River), soil contamination.

- Public/stakeholder acceptance of final cleanup initiatives.

- Understandability and defensibility.

- Quality management.

- Natural ecosystem impacts.

- Impacts on special species.

(a) The "TWRS New Technical Strategy" was presented as a staff recommendation to the TWRS Leadership Council on February 4 and 5, 1993. 
- Minimize long-term environmental contamination.

- Maximize unrestricted land availability by minimizing on-site low-level waste volume.

- Minimize off-site waste volume.

- Minimize volume of other system generated waste.

- Minimize worker/public radiological exposure.

- Minimize worker industrial hazards.

- Minimize public transportation hazards.

- Minimize time duration for resolving environmental concerns.

- Minimize campaign duration.

- Minimize time duration for resolving safety issues.

- Maximize early immobilization for disposal progress.

- Minimize total life cycle cost.

- Minimize discounted costs.

- Maximize use of mature processes.

- Maximize flexibility and adaptability for new technologies.

- Avoid regulatory uncertainty.

- Ability to achieve standards with a degree of certainty; now and in the future.

- Public perception.

- Tribal rights.

- Maximize operability and reliability.

- 100 years after closure of Hanford - want to be able to use Central Plateau for general use.

- Provide for the greatest range of possible future uses of the Hanford Site.

- Minimize irrevocable commitments of land and resources.

- Do it expeditiously (schedule progress and assurance).

- Do the job efficiently (cost effective).

Assessing Technologies for the Treatment of Tank Wastes at DOE's Hanford Site (von Winterfeldt 1993)

- Economic concerns: budget realities, cost profile.

- Defensibility of technical solutions.

- Environmental concerns: biota--natural ecosystem impacts, impacts on special species; not-biota-air contamination, groundwater contamination, surface water contamination (Columbia River), soil contamination.

- Meet Tri-Party Agreement milestones.

- Avoid focus on short-term problems.

- Keep focus on long-term needs and goals.

- Broad and early stakeholder involvement.

- Political and institutional support.

- Maintain evolving strategy in touch with stakeholders.

- Public/Stakeholder acceptance of final cleanup initiatives. 
- Appropriate use of research and development.

- Yakima Nation special concerns: ability to exercise rights, cultural rights (practicing religion), concern with desecrating sites of religious significance.

Tank Waste Decision Analysis Report (Johnson et al. 1993)

- Strive for volume minimization.

- Minimize long-term environmental contamination.

- Maximize unrestricted land availability by minimizing on-site low-level waste volume.

- Minimize worker/public radiological exposure.

- Minimize worker industrial hazards.

- Minimize public transportation hazards.

- Minimize time duration for resolving environmental concerns.

- Minimize campaign duration.

- Minimize time duration for resolving safety issues.

- Maximize early immobilization for disposal progress.

- Keep technical options open that have realistic, cost-effective chances to significantly improve waste management practices over the life of the cleanup and appropriately implement these options.

- Use the most practicable, timely, available technology, while leaving room for future innovations.

- Minimize total life cycle cost.

- Minimize discounted costs.

- Technology assurance.

- Maximize operability and reliability.

- Minimize time duration for resolving environmental concerns. 



\section{Distribution}

No. of

Copies

\section{OFFSITE}

12 DOE/Office of Scientific and Technical Information

Jim Creighton 203 Tait Avenue

Los Gatos, CA 95030

Helen Latham

505 King Avenue

Columbus, $\mathrm{OH} 43201$

Detlof von Winterfeldt

Decision Insights

4590 McArthur

Suite 500

Newport Beach, CA 92660

\section{ONSITE}

6 Westinghouse Hanford Company

M. L. Grygiel (5)

S. K. Murdock
No. of

Copies

\section{ONSITE}

30 Pacific Northwest Laboratory
A. J. Brothers
L. L. Dirks (10)
R. A. Fleshman
K. M. Fowler
B. L. Harper
W. A. Hesser
V. L. Hunter
M. S. Madden
N. M. Pyron
M. J. Quadrel
M. A. Robershotte
D. A. Seaver
W. G. Stillwell
M. B. Triplett
B. K. Wise
Publishing Coordination
Technical Report Files (5) 


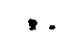

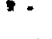

- $\because$

'.

$\because$
$\therefore$ 